知られているようで，交替性転向反応と名づけられ，我 が国でも 1950 年代からいくつかの実験的な研究がなさ れている。

交替性転向反応は, オカダンゴムシだけではなく昆虫 類, 魚類, 鳥類, 哺乳類にまでみられる, 動物にとって はかなり普遍的な行動のようであり ${ }^{(1)}$, ダンゴムシやワ ラジムシ (Porcellio scaber) など等脚目における研究は かなり盛んに行なわれている。これはひとえに実験動物 入手の容易さ, 飼育の容易さなど, 研究者にとって実験 遂行上の都合に負うところが多いように思われる。さて 本稿では，オカダンゴムシの交替性転向反応に関わるこ れまでの研究と今後の課題などについてご紹介する. 読 者諸氏も子供時代に返って, 夏休みの課題よろしくこの 愛らしい生き物と戯れてみてはいかがだろうか。

少々堅苦しい話から始まってしまうが，動物の行動分 析には, その行動のメカニズムを解析すること（至近要 因）と，彼らが生存する上でその行動にどのような意味 があるのかを解析すること（究極要因）の両方の視点が 必要である。オカダンゴムシの交替性転向反応に関して も，これらの視点から研究がなされてきたが，初期の頃 は，主に前者の視点に関するものであった。たとえば， 1950 年代に報告された岡山大学の渡辺, 岩田の一連の研 究 ${ }^{(2 \sim 5)}$ は代表的なものであり, 様々な実験装置を工夫し て行動を分析し，どのような刺激の受容が関わっている のかを解析している。

その後, より詳細なデータに基づいて, 交替性転向反 応のメカニズムの解明が試みられた ${ }^{(6)}$. 中でも Hughes は, 一連の研究に基づいて BALM (bilaterally asymmetrical leg movements, 左右非対称脚運動）という仮 説を提案した ${ }^{(7)}$.これは, 歩行する際に左右の脚の活動量 をなるべく均等にしようとするメカニズムを想定し，一 度ある方向に転回し脚の活動に非対称が生じると, それ を取り返そうとする活動が生じる，すなわち，次は逆方 向に転回することとなる，というものである。なかなか 興味深い仮説であり，これによって説明がつく多くの実 験結果もあるが，一方では，さらに検討を要すると思わ れる問題点の指摘もある。たとえば，本年 4 月の日本応 用動物昆虫学会大会では，サーボスフェアという非常に 巧妙な行動解析装置を用いた，オカダンゴムシの交替性 転向反応に関する報告がなされた ${ }^{(8)}$ 。この中で，交替性 転向反応は, BALM ではなく走触性（後述）によってか なりの説明がつくのではないかとの興味深い指摘がなさ
れた。また，筆者が行なった直線歩行路における反応(後 述）もこの仮説だけでは説明ができない。この問題につ いては, 今後さらに行動の発現機構に関する知見の蓄積 が待たれるところである。なお，メカニズムの分析とい う視点に立てば，当然，行動を制御している神経機構の 分析も必要となるが，現在のところ，等脚目を用いた研 究はほとんどないようである。

一方，オカダンゴムシが交替性転向反応を示す意味に ついては，それほど多く研究されているとはいえない。 そのような背景において森山は, オカダンゴムシの歩行 行動が継続された場合に，環境の違いに応じてどのよう な行動の可塑性がみられるのか，あるいはどのような意 思決定がなされるのかという問題を，無限に転回を継続 させることができる巧妙な装置を用いて分析してい る(9).その結果に基づいて, 行動のコンピュータシミュレ ーションも行なわれておりり ${ }^{(10)}$, 交替性転向反応の究極的 な進化要因の解明とともに，行動の背景にある神経メカ ニズムの解析にも大きなヒントをもたらすことになると 期待される。

さて, そんな中で, 筆者は過去の研究者が行なった実 験結果を類似の装置を用いて確認したり，また新たな発 想に基づいて装置を工夫して調べた ${ }^{(11)}$ 。その実験のいく つかを，以下に紹介する。

\section{1. $\mathrm{T}$ 字路での方向選択}

最初にこの性質を知ったときに，「本当だろうか」と筆 者は半信半疑であった。そこで，さっそく過去の様々な 資料を参考に図 1 に示すような $\mathrm{T}$ 字路が連続する装置 を作成し，オカダンゴムシに歩かせてみた。その結果， 前にした転向と逆転向(右 $\rightarrow$ 左, 左 $\rightarrow$ 右)する比率は $85 \%$ 以上であり, 交替性転向反応の存在は明らかであった。

このような反応は自発的な転向の際に生じるものなの

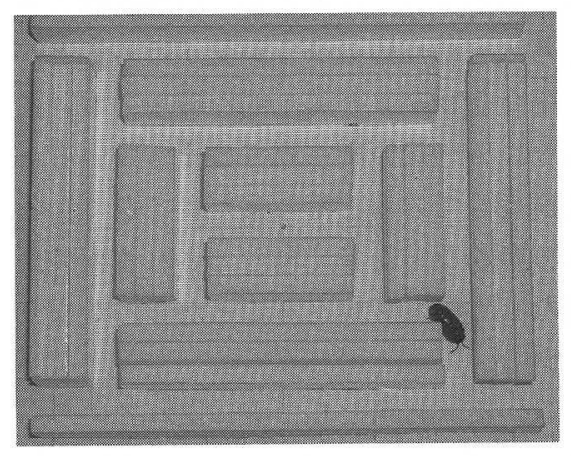

図 1 日 $\mathrm{T}$ 字路が連続する迷路状の装置内を歩くオカダンゴ ムシ 


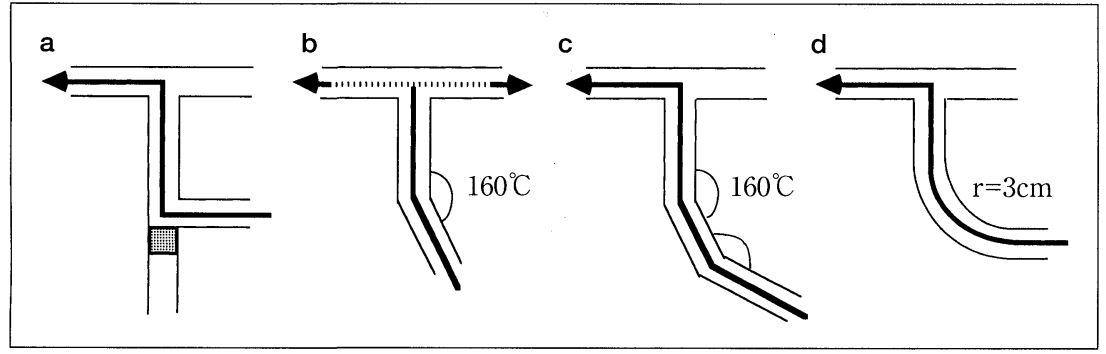

\section{図 2 実験に用いた各種の歩行路と T 字 路の選択}

$\mathrm{a}$ : 強制的な転向後の選択, $\mathrm{b}: 160^{\circ}$ の転向の 後の選択, $\mathrm{c}: 2$ 回の $160^{\circ}$ の転向の後の選択, $\mathrm{d}$ : 半径 $3 \mathrm{~cm}$ のカーブの後の選択

だろうか，また歩行路の形状からやむを得ず強制的に転 向させられた場合でも同様の反応が生じるのだろうか. これを調べるため, 以下の実験を行なった。一方は左側 への転向が歩行路の封鎖によって阻止され右折を強制さ れた場合（図 2-a），他方は両歩行路とも開放されてい

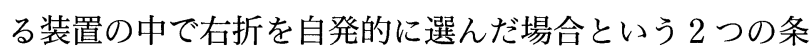
件をつくり，次の $\mathrm{T}$ 字路でどちらに転回するかを調べ た。その結果， 2 条件間で差はまったくみられず，交替 性転向反応は自発的な転向でなくても生じるということ がわかった。

では，最初の転向角度を徐々に鈍角にしていった場 合，次の転回で逆方向を選ぶ傾向がみられるのはどの角 度までであろうか (図 2-b). 最初の転向角度を $90^{\circ}$ か

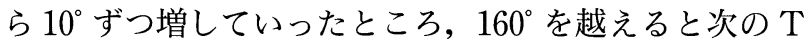
字路での選択に偏りがなくなり，左右半々となった。つ まり，彼らは $160^{\circ}$ 以上の角度は直線と区別していない と考えられる。ところが，興味深い事実が後からわかっ てきた。 $160^{\circ}$ の転向は単独では直進と同じ結果になる が，2回続けると，次の選択では明確に逆方向を選ぶの である (図 2-c)。これは，前述の Hughes の BALM 仮説を支持するように思われた。すなわち，転向角度が ある限度を超えると両脚間の活動量の非対称性はあまり 大きくなく，直線を歩行する場合と大差はないので，前 の転向の影響が次の転回には現われない。しかし，その 角度を 2 回連続して転回させると活動量に明らかな非対 称が生じ，前回とは逆方向の転回をしたと解釈できる. なお，交替性転向反応は，直線的な角度の転回ではなく て緩やかな弧を描くカーブ（半径 $3 \mathrm{~cm}$ のカーブ）にお いてもみられることが確認されている(図 2-d).

\section{2. 十字路での転向反応}

ところで，歩行中に十字路に遭遇した場合はどのよう な反応をするのであろうか.この点について, 図 3 に示 すような歩行路を作って，転向の様子を観察した。その 結果, 直線通路を歩行している中で十字路に遭遇すると 80\%の個体が転回することなくそのまま直進するが，十 字路に至る前に転回していると，十字路で約 $75 \%$ の個体
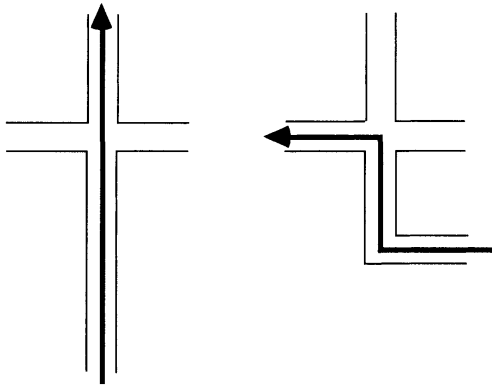

\section{図 3 -十字路での進路の選択}

が直前とは逆方向に転回するということがわかった

\section{3. オープンスペースでの進路選択}

では，もし通路からオープンスペースに出た場合はど のような反応がみられるのであろうか.これを調べるべ く, 歩行路から $180^{\circ}$ の角度でオープンスペースが広がる ような設定を作り (図 4-a, b)，直線歩行路および転回し た歩行路からオープンスペースに出た場合それぞれにお ける, 出口から一定距離を歩行したときの所在位置の分 布を調べた。すると, 直前に転回し, オープンスペース に出た場合, 明らかに逆の方向に歩行する傾向がみられ た.

これらの実験からわかるように，直前の転向が次の転 回に影響を与えることは明らかである。では，その影響 はどれほどの距離あるいは時間維持されるのであろう か. 図 2-a に示した装置をもとに, 最初の転回後, 次の $\mathrm{T}$ 字路に至るまでの距離を徐々に伸ばしていって, 転回 率を測定してみた。その結果, 直線歩行距離が $15 \mathrm{~cm}$ を 越えると, ランダムな転回の場合と差がなくなることが わかった。このことから，オカダンゴムシには転回方向 の記憶が存在し, 一定距離を歩行するとその記憶が失わ れるということが示唆され, 実に興味深い. しかし, 他 の様々な解釈も可能であり, 直ちに $15 \mathrm{~cm}$ の歩行（ある いはそれに要する時間経過）によって記憶が失われると いう結論を出すのはまだ早い.この点については, 現在, 

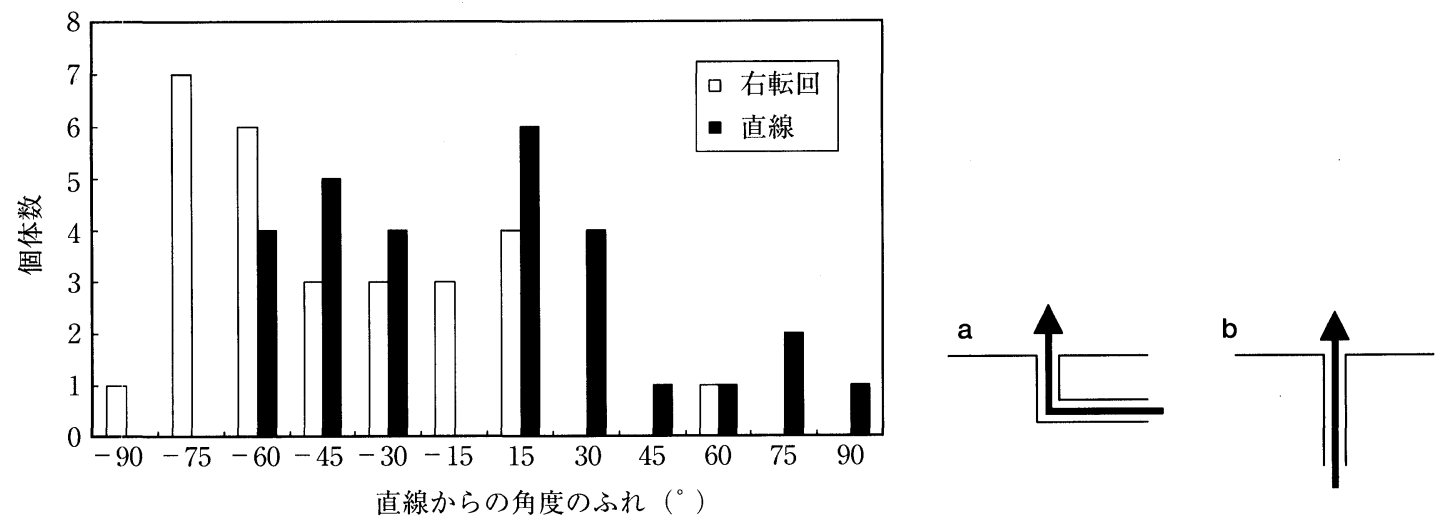

図 4 右転回の後（a）および直進してからオープンスペースに出た場合（b）の進路の選択

前出のサーボスフェアを利用した解析が行なわれてお り, 至近要因の探求と併せて, さらなる検討結果の報告 が待たれる。

以上の実験については，原則として雄個体を用いて行 なったが, 雌雄間で反応に違いがあるかどうかを比較し たところ，差はまったくみられなかった。このことは， 雄あるいは雌という性に固有な要因ではなく, 両性に共 通する究極要因があることを示唆していると思われる.

\section{4. 足跡フェロモンの影響}

一つの可能性として, オカダンゴムシのように地表面 を徘徊する動物の場合, 足跡フェロモンのような同種他 個体の歩行に影響を及ぼす化学物質を残す可能性がない とはいえない.この点を確認するため, 図 2-a に示す装 置の一部 ( $\mathrm{T}$ 字路左側) を封鎖して, 2 回の連続した右転 回を, 20 個体に続けて歩行させた直後に封鎖を解除し, その後, 別の個体を歩かせ進路選択を調べた。 その結果, 実験前に行なった 20 回の「跡づけ」の効果はみられず， その後の歩行個体の行動にはまったく影響がないことが わかった。すなわち, 交替性転向反応に足跡フェロモン が関与している可能性はないと推測された。 ただし, オ カダンゴムシに関しては集合フェロモンの存在が報告さ れている(12). 実験の設定次第では, 他の個体がいる（い た）場所はそのフェロモンによって，後に訪れたオカダ ンゴムシの行動に何らかの影響を与えることがあるかも しれない.

\section{5. 強制的な歩行路での反応}

さて次に，歩行路の設定によって強制的にある方向へ 連続転回させた場合, オカダンゴムシがどのような反応 を示すのかを調べてみた。 まず，図 5-a に示す直径 8 $\mathrm{cm}$ の円型と一辺 $5 \mathrm{~cm}$ の正方形型の 2 種類の歩行路を 用いて実験を行なった。 その結果, オカダンゴムシは a

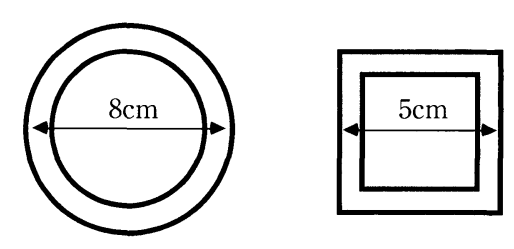

b

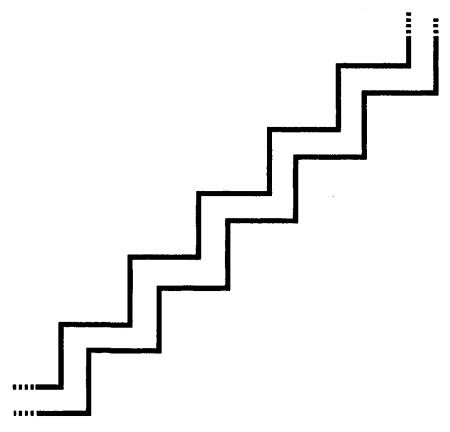

图 5 -歩行継続距離を測定した各種の歩行路

$\mathrm{a}$ : 円型と正方形型の歩行路, $\mathrm{b}$ : 直線とジグザグの歩行路

かなり速やかに通路にそって歩行することを止め（正方 形で平均 $22.9 \mathrm{~cm}, n$ (実験個体数) $=57$, 円形で平均 $31.8 \mathrm{~cm}, n=50), \mathrm{U}$ ターンしたり, 歩行路からの脱出 を試みた。この場合, 円形に比べ, 正方形のほうがやや 早く行動の変化が起こるようであり, U夕ーンや脱出 が生じた場所の分析から，コーナー部分の存在が行動転 換のきっかけとなっていることが推察された.

ところで，すでに述べたように，オカダンゴムシの交 替性転向反応の発現機構に関しては, Hughesによる BALM が一つの有力な仮説とされている.これに基づい て考えると, オカダンゴムシが直線の歩行路が長く続く 状況に置かれた場合, 少なくともある程度の間歩行が継 続され，通路にそって歩くことが予想される．そこで, 長さ $75 \mathrm{~cm}$ の歩行路を作り (図 5-b)，オカダンゴムシを 
入れた。すると予想に反して，ある程度の歩行の後，多 くの個体が U ターンしたり, 側壁を登って歩行路からの 脱出を試みた（平均歩行距離 $56.1 \mathrm{~cm}, n=30$ )。これに 対し，興味深いことに，同じく全長 $75 \mathrm{~cm}$ ではあるが， $5 \mathrm{~cm}$ ごとに左右交互に $90^{\circ}$ の角度で転回するジグザグ の歩行路を歩かせた場合は，ほとんどの個体が途中で Uターンしたり脱出したりすることなく歩行路にそっ て出口まで歩行を継続した $(72.9 \mathrm{~cm}, n=28)$.すなわ ち，オカダンゴムシはもともと直線的に歩行するより も, 高頻度で転回する環境の中で交替性転向反応を示し て歩行するほうがより安定的に歩行を継続するのであ る。言ってみれば，「オカダンゴムシはジグザグが好 き!」なのである。

直線の歩行路で転回したがるのであるなら，途中に出 口があったときはどうするのであろうか。そこで，直線 の歩行路ではあるが，途中 $5 \mathrm{~cm}$ おきに両側に出口を設 けた歩行路を歩かせてみた。その結果，オカダンゴムシ は予想通りかなり早く歩行路から脱出する傾向がみられ た（平均歩行距離 $37.0 \mathrm{~cm}, n=30$ )。通路状の歩行路て はなく，片側を壁のようにしてそれにそって歩行させた ら，少なくとも片側はいつでも脱出可能である．このよ うな場合も同様に，早く歩行路（壁）から離れるのであ ろうか。調べた結果，不思議なことにオカダンゴムシは 上記の直線歩行路の場合と同じ程度に歩行することがわ かった（平均歩行距離 $52.3 \mathrm{~cm}, n=40$ )。このことにつ いては，今のところどのように理解したらよいのかよく わからないが，少なくともオカダンゴムシには明らかに 強い走触性が存在することは事実である。走触性とは多 くの動物にみられる行動で，たとえば読者のお宅でも嫌 われものになっているゴキブリがよくやる, 部屋の壁際 を走るあの行動である。オカダンゴムシの歩行行動に走 触性が関わっているのは間違いないと思われるが，交替 性転向反応とどのように関わっているのかは, 大いに検 討の余地があるように思われる。

以上のように，様々な装置を設定し歩行させた場合， オカダンゴムシは実に興味深い歩行行動を示すことが明 らかとなった。では，これらの結果をどのように組み合 わせれば交替性転向反応のメカニズムがみえてくるの か，前述した記憶の存否，走触性の関わり方，またその 背景には, どの器官からの接触刺激の受容が役割を果た しているのか, どんな神経機構が関わっているのかなど, 解明されるべき課題は多い。新たな発想に基づく研究の 今後の発展が待たれるところである。

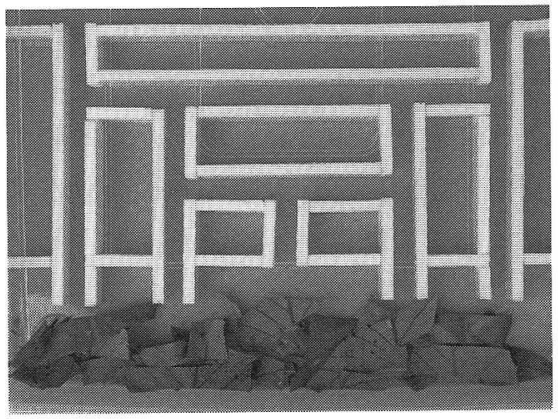

図 6 自発的歩行と逃避的歩行での進路選択と歩行速度を 調ベた実験装置

オカダンゴムシが歩行によって移動するのは，䬣や繁 殖相手を求めてそれまでいた環境から新たな環境に自発 的に進出する場合，たとえば何らかの危険が身に迫った ためにそれまでいた環境からやむを得ず逃避するという 場合が考えられる。このような状況の違いによって，も 儿交替性転向反応にも何らかの差がみられるのであれ ば，これは交替性転向反応の適応的意義を考える上で一 つのヒントになるかもしれない。

ワラジムシについては，歩行行動を開始するきっかけ の違いがその直後の行動，特に交替性転向反応の発現の しかたにどのような変化を及ぼすのかという視点で，天 敵からの逃避を想定した実験がある ${ }^{(13)}$ 。筆者はこの実験 にヒントを得て，オカダンゴムシについて図 6 に示す装 置を用い実験を行なった。連続した $\mathrm{T}$ 字路の入り口の周 囲に落ち葉を置いて通常の生活環境と同じょうな状態に し，その場所からオカダンゴムシが自発的に中央の入口 より T字路に入った場合，どのような経路を選択するの かを観察した。オカダンゴムシは夜間に活発に活動する 傾向があるため，この観察は赤外線ビデオカメラによっ て録画した映像から行なった。一方，この結果と対比す るために, 同じ装置の T 字路入り口に人為的にオカダン ゴムシを指でつまんで置き，その後の行動を同様に観察 した。この「指でつまむ」という行為は天敵との遭遇を 模したもので,オカダンゴムシ特有のダンゴ状態にして, 入口に置いた。つまり，慨や繁殖相手探索のために自発 的に T 字路に入った場合と, 天敵から逃避を行なうとい う状況で強制的に T 字路に入った場合とで, その後の行 動に差があるのかどうかを調べたのである。

その結果，強制的（逃避的）状況の中では自発的な場 合に比べ，交替性転向反応がより確実に現われる（連続 2 回の転向で逆転回した比率は，強制的歩行で $88 \%$ ，自 発的歩行で 78\%）と同時に，歩行路内の歩行速度（強 
制的歩行では $0.89 \mathrm{~cm} /$ 秒，自発的歩行では $0.66 \mathrm{~cm} /$ 秒）が速いことがわかった。つまり，身に危険が迫った 状況ではより速くより確実に今までいた場所から離脱す るという意味で, 交替性転向反応は天敵からの有効な逃 避行動として機能している可能性が示された。

オカダンゴムシは実に身近なありふれた生き物であ る. 彼らの神経系がどれほどの数の神経細胞でできあが っているのかはよく知らないが，せいぜい数万から数十 万といったところではないだろうか.このわずかな数の 神経細胞で複雑な記憶や学習はもちろん, 気のきいた行 動を制御することなんかできるはずがない.この問題に 取り組み始めた当初は, そのような気持ちから，この行 動の背景にはかなり単純なプログラムが存在し, 極端な 言い方をすれば，「たかがダンゴムシ，ダンゴムシロボ ットくらいできるのでは」などとのあなどりの気持ちを もっていた，しかし，やはりさすがは生物！それもオ カダンゴムシが属する甲殼綱は, 何億年もの進化の歴史 をもつ生物群である. 交替性転向反応は確かにちょっと みたところ，単純そうな行動ではある．しかしその背景 にあるメカニズム, 行動の意味は 100 億ほどの脳細胞を
もつ人間がいろいろ考えても未ださっぱりわからないと いうのが実状である。もっとも，私の場合にはその 100 億はとりわけ衰退しているのかもしれないが，実感とし ては，悔しいながら今のところ，T字路が続く迷路を 歩くダンゴムシを見ては「へェー！」とつぶやくのが精 一杯である。

この拙文をまとめるにあたって, はこだて未来大学森山徹氏, 京 都大学佐久間正幸氏から有益な助言をいただいたことを記し, 謝意 を表します。

\section{文献}

1) R.N. Hughes: "Spontaneous Alternation Behavior". Springer-Verlag, 1989, p. 39.

2）渡辺宗孝，岩田清二：動物心理学年報，6, 75 (1956).

3）岩田清二，渡辺宗孝：動物心理学年報, 7, 53 (1957).

4）岩田清二, 渡辺宗孝：動物心理学年報, 7, 57 (1957).

5）岩田清二，渡辺宗孝：動物学雑誌，12, 468 (1957).

6) I. Kupfermann : Anim. Behav., 14, 68 (1966).

7) R.N. Hughes: Anim. Learn. Behav., 13, 253 (1985).

8）平井真, 福井昌夫, 小野知洋, 佐久間正幸：「第 48 回日本応 用動物昆虫学会大会講演要旨 $」, 2004$, p. 208.

9) T. Moriyama: Int. J. Comp. Psychol., 12, 153 (1999).

10) M. Migita \& T. Moriyama : "AIP Conference Proceedings, 718”, 2004, p. 451.

11）小野知洋, 高木百合香 :「第 48 回日本応用動物昆虫学会大会講 演要旨 $\rfloor, 2004$, p. 207.

12) N. Takeda : Experientia, 36, 1296 (1980).

13) G.D. Carbines, R.M. Dennis \& R.R. Jackson : Int. J. Comp. Psychol., 5, 138 (1992).

\section{プロ}

浅見 忠男 (Tadao Asami) 昭和 33 年 10 月 16 日生 $<$ 略歷 $>1982$ 年東京大学 農学部卒業 / 1987 年同大学大学院農学 研究科農芸化学専攻博士課程修了（農 博) /同年日本特殊農薬製造(株)（現 バ イエルクロップサイエンス）勤務/1991 年理化学研究所 (現 独立行政法人) 研究 員 $/ 2000$ 年同研究所副主任研究員, 現 在にいたるく研究テーマと抱負 $>$ 植物生 理活性物質の創製を行ない植物生命現象 の解明へと応用するだけでなく, 今後は 人と植物の物質的相互作用についても追 求していきたいく趣味>読書, 球技

伊藤 敏幸（Toshiyuki Itoh） 昭和 29 年 1 月 11 日生 $<$ 略歴> 1976 年東京教育 大学農学部農芸化学科卒業後, 三重県立 高校教諭 (桑名工業高校, 神戸高校) ／ 1987 年岡山大学教育学部助手 $/ 1988$ 年 同講師 $/ 1990$ 年同助教授 / 2001 年鳥取
大学工学部助教授 $/ 2004$ 年同教授, 現在 にいたる.この間, 1981〜 87 年三重大学 工学部研究生, 1990 91 年米国コロラド 州立大学化学科博士研究員. 1986 年理博 (東京大学) <研究テーマと抱負 $>$ 新しい イオン液体の合成，イオン液体を反応媒 体とする反応開発（酵素反応と電子移動 型触媒反応), ポイントフッ素化による 機能性分子の合成 (gem-ジフルオロシク ロロプロパンとポイントフッ素化フェロモ ンの不斉合成), 糖-Scaffold による不斉 合成反応の開発 <趣味 $>$ 写真（最近はデ ジタルカメラが主です), 登山, スキー

池野 聡一（Souichi Ikeno） 昭和 41 年 10 月 19 日生 $<$ 略歴>平成 4 年昭和薬 科大学大学院薬学研究科修士課程修了／ 同年同大学生化学研究室助手, 現在にい たるく研究テーマと抱負>カスガマイシ ン生合成とその排出に関する分子遺伝学
的研究. 放線菌が生産する二次代謝物の 生産制御機構に関することは何でも知り たいく趣味＞美味しいコーヒーを飲むこ と

小野 知洋 (Tomohiro Ono) 昭和 23 年 12 月 11 日生 <略歴> 1971 年名古屋 大学農学部農学科卒業 $/ 1977$ 年同大学 大学院農学研究科博士課程修了(農博) / 1978 年金城学院大学短期大学部講師／ 1982 年同助教授 / 1990 年同教授 / 1997 年同大学現代文化学部教授, 現在にいた るく研究テーマと抱負>昆虫などの行 動, 特に繁殖戦略の比較<趣味>細々し たものを手作りすること

大森 義裕 (Yoshihiro Omori) Vol. 42 , No. 5 , p. 325 参照 